が期待できる分野である，基調講演（C-102）は，浜松ホ トニクスの松本氏による「レーザーによる樹脂材料の接合 技術について」であった.レーザーによる樹脂融着は，浜 松ホトニクスが 20 年以上も前から検討を行い, トヨタ自 動車が 15 年以上前に量産に適用した.このように古くか らある技術ではあるが，あまり一般化していないレーザー 樹脂融着の接合の際に起こる現象について説明して頂いた. レーザー加熱の局所性により, 材料を急加熱することがで きる.これより材料が膨張し溶融した樹脂が流れる.この 樹脂の高速な流動がレーザー樹脂融着において非常に重 要な役割を果たしていることを実験結果をもとに紹介さ れた。

一般公演では, 加工法と品質評価についての講演があっ た. 波長 $2 \mu \mathrm{m}$ のファイバレーザーを用いた透明樹脂同士 の融着について紹介があった $(\mathrm{C}-104)$ 。透明樹脂 (PMMA， PVC，PCなど）は波長 $2 \mu \mathrm{m}$ に吸収があるため，この波
長を用いれば，透明樹脂同士の接合面に光吸収剂を塗布す るなどの前処理なく，接合が可能になる．また，レーザー を用いたプラスチックの染色法について紹介があった（C -105). 従来は, プラスチックを染色液の中に浸せきして いた，本手法により，色合わせが容易になり，廃液もなく なることが報告された。透明プラスチックのレーザー融着 品質評価法として, 製品にシャックハルトマン波面セン サーを用いたシステム（C-106）や偏光イメージングを用 いた樹脂材料の可視化・分析システム（C-107）について 紹介があった。これらにより, 透明樹脂の加工の定量的な 評価ができることを示した．このような測定技術の進展は， 加工技術の進展に欠かすことのできないものである.

本セッションの会場には多くの聴講者が参加し, 活発な 議論が行われ，本分野に対する関心の高さを感じた．今後， レーザーによる樹脂材料の加工技術進展により，より良い 製品が作られることを期待する.

\title{
未来を切り開く Cutting-edge な複合材料技術
}

$(\mathrm{B}-101 \sim \mathrm{B}-109)$

現在の複合材料研究に打いて, 高性能な複合材料の量産 化, 実用化に向けた取り組みに注目が集まっている.本セッ ションでは複合材料の成形に関する研究を中心に, 初日の 午前中に基調講演 1 件を含む 8 件の講演がなされた。

B-101 では, マット材を強化形態とした熱可塑性樹脂複 合材料のプレス成形における瀻維配向変化の可視化, 定量 化について報告された.コンプレッション成形において, 成形時に流動を伴った場合の瀻維配向予測は課題であるが, 本研究ではX 線の技術を用いることにより, 内部の流動 に関しても可視化できる技術について述べられた。このよ うな技術の進歩により, 今後, 成形後の力学的特性予測技 術の実現が期待される報告であった，B-102 は，PA 12 に 対して纎維/樹脂界面の接着性を向上させることを目的と してマレイン酸変性 PPを少量添加したフィルムを用いた 場合の成形条件と成形性に関して述べられた。 ある成形条 件においてボイド率が低減し，成形性が大幅に向上する事 が報告された. B-103は, 連続瀻維の複合材料と射出樹脂 を組み合わせたハイブリッド成形に関する最適化の報告で あった。連続繊維強化複合材料の予備加熱に, 中赤外線お よび気相加熱の 2 種類の方法を用い, 内部の温度プロファ イルに関して詳細に検討された。また，ハイブリッド成形 品の力学的特性に関する影響についても述べられ, 使用す る成形用中間材料に応じて加熱条件, 加熱手法を変える必 要があることが示された，B-104では，連続緘維熱可塑性 樹脂複合材料成形のハイサイクル化を目標として, スタン ピング成形に急速加熱可能なヒーターを用いた検討がなさ れた。この結果, 成形品の表面品質抒よび力学的特性が通

\footnotetext{
* Ohtani, Akio

京都工芸繊維大学 繊維学系 先端ファイブロ科学専攻

京都市左京区松ヶ崎御所海道町（７606-8585）
}

\section{大 谷 章 夫*}

常のヒーターと同様であることが確認され，大幅な成形時 間短縮の可能性が見いだされた，B-105では，高品位な熱 可塑性樹脂複合材料の成形を目指して, 予備加熱に気相加 熱法を用いた場合の, 成形品の温度プロファイルおよび力 学的特性への影響について検討がなされた。 その結果, 板 厚方向の温度分布の均一性が確認され, 偏肉な成形品の予 備加熱に適した加熱手法であることが確認された，B-106 (基調講演) では, 兵庫県立大学の岸先生より, 熱可塑性 アクリル樹脂を用いた複合材料の成形および力学的特性改 善に関する研究についてご講演いただいた，モノマー状態 で含浸がなされるため, 成形性が非常に良いことや，界面 特性向上に関する知見が述べられた。 アクリルを用いた複 合材料はあまり注目されていないが，成形時の利点や界面 特性向上の可能性が示されていたことから, 今後の利用が 期待される研究報告であった. B-108では, 強化基材とし て注目されている NCF (Non-Crimp Fabric) に 3 次元形 状を賦形した際の, 纎維配向の変化や纎維束間の目開きに ついて，FEM 解析を用いた予測が検討された。瀻維束お よび縫合糸のモデル化を行うことにより, 賦形状態の予測 が可能であることが示された，B-109では，天然纎維であ るラミー瀻維とバイオプラスチックである PLA と PBAT のアロイを用いた複合材料に関して, ラミー瀻維の $\mathrm{NaOH}$ 処理条件抄よび試験速度が力学的特性に及ぼす影響につい て検討がなされた. $\mathrm{NaOH}$ で処理を行うことにより，ひ ずみ速度が大きい場合で強度や破断変位の向上が見られた。

セッション全体を通して聴講者は多く, 議論も活発に交 わされており, 複合材料の成形加工に関する関心，期待が 高いことが伺えた. 
本セッションは大会 2 日間を通して講演がおこなわれた. ここでは，2 日目の 8 件（うち基調講演 1 件）の発表につ いて報告する．発表内容は，リサイクル技術に関するもの が 1 件, 複合材料の物性に関するものが 4 件, 樹脂含浸特 性に関するものが 3 件であった. 以下にその概要を示す.

岐阜大学の三宅氏に基調講演（B-209）頂き，リサイク ル炭素繊維をスライバとして混練押出しすることにより, 長繊維を残存させて繊維配置の均一な成形体を得ることが でき, その結果高い引張弾性率が達成できることが報告さ れた.

複合材料の物性に関する発表では，B-201 で一方向炭素 繊維強化複合材料 (CFRP) の積層構成が電気・力学特性 に及ぼす影響について発表され, 電気伝導率が高い積層構 成は，曲げ剛性・強度が低いという結果が報告された， B -202では，炭素繊維を含有する成形体における厚さ方向 の熱伝導率を向上させるために，プロセス途中の流動によ り炭素繊維を一方向に配向させた中間シートを作製し, こ

\footnotetext{
* Nanami, Norimichi

岐阜大学

岐皁市柳戸 1-1（舀501-1193）
}

れを二次成形することで繊維配向を厚さ方向に強制的に揃 える手法について発表された. B-203では, モルフォロジー 制御によりCFRP にエラストマーを複合化し，その剛性 とエネルギー吸収性能を高度に両立し得ることが報告され た，B-204では，CFRPに電子線を照射させた試験片を用 いて超高速衝突実験を実施して, その破壊挙動について報 告された.

樹脂含浸特性に関する発表では，B-205 で無水マレイン 酸変性ポリプロピレン（MAPP）が炭素繊維束への樹脂 含浸挙動に及ぼす影響と樹脂と繊維の接着性が含浸特性に 及ぼす影響について発表され，MAPPを添加することで その界面せん断強度が向上するが，樹脂含浸性は低下する ことが報告された，B-206では，CFRP 成形中の金型内に おいて織物のフィラメント数が樹脂含浸特性に与える影響 について発表された。 B-211では，低粘度のポリプロピレ ンを用いて圧縮成形をおこない, その含浸挙動の観察から 得られた粘度と含浸距離の関係について報告された。

全体を通して多くの聴講者が訪れ，議論も活発に交わさ れており，本分野に対する関心の高さを改めて感じ，未来 の市場ニーズを意識した最先端研究開発に期待したい.

\section{先端デジタル技術による設計・成形支援}

$(\mathrm{A}-101 \sim \mathrm{A}-108)$

話題になっているものの，具体的にはあいまいな $\mathrm{AI}$ や IoTを中心として企画した. 成形加工分野での取り組みも 緒に就いたばかりで多くの講演申し込みは難しいことも考 慮し, 先行他分野の方々も含めて, オーガナイザー依頼ベー スの基調講演が多いセッションとなった. 聴講された方々 は, 学会の理事や各委員等も多く, 企画・マネジメントサ イドの方々の関心が強いように見受けられた. 以下, 初日・ 二日目に分けて講演内容を報告する。

基調講演 A-101（埼玉工大 河田）は，切削加工を例と して，加工中の加速度データを収集するとともにリアル夕 イムに過去の良否データと比較解析して不良の発生を抑止 するという先進的な取り組みの紹介であった．解析手法は 品質工学的 MT システムであるが，この部分は AI 的な手 法への置き換えも容易であろう.まさに, 時代の潮流の IoT と $\mathrm{AI}$ の組み合わせの研究である. A-103(埼玉工大 趙ら) はこの考え方を射出成形に試行した研究であり, 成形品 (ダ

\footnotetext{
Takahara, Tadayoshi

(制富士テクニカルリサーチ

名古屋市中区栄 5-28-19 AT 栄 V 11 階（テ460-0008）

兼 埼玉工業大学

深谷市普済寺 1690（† 369-0293）
}

高 原 忠 良*

ンベル試験品）の成形品質をスキャンしてデジタル化し MT 法で良否判別している. 基調講演 A-104（村田機械 木野）も IoT\&AI の先進事例である. 射出成形中の温度・ 圧力・型位置情報を収集し，その波形を機械学習すること で自動判別するものであり，数千から数万のデータの集約 散布図は圧巻である。講演ではデー夕分布が日々変動する さまを連続的に映写していたが，多くのデー夕集積から見 えてきた挙動である. 継続的にデー夕を蓄積・解析するこ とでこれまで探索しきれなかった新たな傾向発見の可能性 を示唆している．基調講演 A-106（産総研/大阪大 鷲尾 ら）は AI と CAE を融合することにより画期的な効率化・ 品質向上が可能となる設計支援方法の紹介である．解析パ ラメー夕設定に過去の解析結果の機械学習を用いる，複雑 な解析モデルそのものを機械学習によって簡素化し高速 · 効率化を図るなどといった考え方である，修理不可能な宇 宙望遠鏡の光学設計にこのアプローチを活用し, 従来手法 の 105 倍の効率化例を紹介していた，A-108（東レエンジ ニアリング 山田）は射出成形 CAE に AI 技術を適用する 事例である. 今後, 商用ソフトにも機械学習機能を組み込 み効率化が進む方向性を示す内容であった。 